U.S.S.R. with the setting up of bacteriophage research institutes at Tiflis, Kiev and Kharkov.

In 1917 in a note to the French Academy, d'Herelle published his epoch-making observations "Sur un microbe invisible, antagoniste des bacilles dysenteriques", wherein he gave a description of the phenomenon of bacteriophage which bears his name. The phenomenon of bacteriophage had no doubt been discovered earlier by Twort (1915), but the graphic description given by d'Herelle, on his independent discovery of it, startled the scientific world to the extent that the discovery was immediately appreciated as one of the greatest of the century. In this connexion it is worthy of remark, in passing, that through two of her sons, d'Herelle and Banting, Canada stands associated with the two most outstanding and far-reaching medical discoveries of the first quarter of the present century : bacteriophage and insulin.

A recipient of many honours, there were two of which he was specially proud: the Leeuwenhoek Medal of the Amsterdam Academy of Science (1925), and the M.D. of Leyden (1923). The former he valued because the only previous French man of science to receive the distinction was Louis Pasteur (1895); and the latter because among the very few British recipients of a doctorate of the University of Leyden was Mr. Winston Churchill.

Of d'Herelle's better-known English writings, mention may be made of "Immunity in Natural Infectious Disease" (1924), which was followed by "The Bacteriophage and its Behaviour" (1926), "The Bacteriophage and its Clinical Applications" (1930), "Studies on Asiatic Cholera", the latter in conjunction with Malone (1930); while his main writings in French were : "Le Bacteriophage, son rôle dans l'Immunité" (1921), "Les Defences de l'Organisme" (1923), "Le phénomène de la guerison dans les maladies infectieuses" (1938), "Etude d'une maladie : le cholera, maladie aux paradoxes" (1948).

For reasons difficult to understand, the therapeutic aspects of his work never enjoyed the support and enthusiasm in Britain that they achieved elsewhere, which must have been a deep disappointment to him, though he avoided speaking of it in that way.

A clear thinker, with an impeccable laboratory technique, and endowed in high degree with the logical outlook of his race, d'Herelle appeared at times somewhat intolerant to those who differed from him; yet, to his friends and associates, he was one of the kindest and most loyal of men. To have known him at all well was indeed a 'liberal education' and a very great privilege.

In 1893 d'Herelle married Marie Caire, who predeceased him ; and they are survived by two daughters and three grandchildren.

A. COMPTON

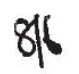

\section{Dr. R. P. Penrose}

REginald PHACY Deykose, whose premature death occurr of Corssentar, near Leyden, on April 28, was educaft at Altrincham Grammar School, where hip distinguished scholastic work was crowned by Mal Open Scholarship to the Queen's College, Ex. He went into residence in 1939, and took the shortened Final Examination in Physics two years later. He then joined the Admiralty research group at the Clarendon Laboratory, Oxford, where he assisted in the design of test equipment for centimetre wave magnetrons.
Towards the end of the War, Penrose developed a method of measuring the dielectric properties of solids at centimetre wave-lengths, using an $H_{0}$-cavity resonator. He pushed this technique a stage further in the analysis of the inversion spectrum of ammonia, the first step in opening up the field of microwave spectroscopy. The award of a Senior Studentship of the 1851 Exhibition in 1946, the year in which he received the degrees of M.A. and D.Phil., enabled him to continue his researches in Oxford on collision broadening, while a year later he turned to break fresh ground in low-temperature work on paramagnetic resonance. He went to Leyden last autumn on an exchange scheme between the Clarendon Laboratory and the Kamerlingh Onnes Iaboratory with the intention of continuing his work there for six months, before taking up a lectureship at the University of Leeds. Just before Christmas he discovered the hyperfine structure of the paramagnetic resonance line in a diluted crystal of copper potassium sulphate, that is, the effect due to the interaction of the nuclear spins with the electron spins (see p. 992 of this issue of Nature). This was the first time such an effect had been observed in an atomic transition in the solid state. The publication of his work, however, was delayed by his illness. He had to undergo an operation, and although he appeared to be making a complete and successful recovery, he collapsed suddenly in the hospital at Wassenaar a few days later.

Dr. Penrose's chief relaxations were photography and cycling, and there were few byways near Oxford unknown to him. His life centred in his research, however, and his enthusiasm in following up a new idea led him to make much of the apparatus himself, for he was a skilful machinist. A cheerful companion, he was liked by all ; I was particularly fortunate in enjoying four years of close partnership with him in the Clarendon Laboratory. Our intimate relationship did not cease when he left Oxford, and the exchange of results and ideas with him will be greatly missed. His death at the age of twenty-eight deprives microwave physics of one of its exponents, and his scientific papers (some of them yet to appear) form the memorial to his pioneer work in this field.

\section{B. Bleaney}

\section{Dr. A. D. Imms, F.R.S.}

Dr. M. Afzal Husain, president of the Pakistan Biological Society and of the Pakistan Association for the Advancement of Science, writes :

The news of Dr. A. D. Imms's death has been received y th deep sorrow in entomological circles in Pakiston. Besides making outstanding contributions to I/dian entomology in his capacity as a former forst entomologist in India, Prof. Imms trained under his inspiring guidance many workers prominent to-day in the field of entomology. The magnitude of his contribution to the development of entomology in Pakistan and the other countries of the Commonwealth in his capacity as a teacher at the University of Cambridge will probably outweigh in value even his direct contributions to the science of entomology, outstanding as these latter are. The numerous schools of investigation and research he thus helped to bring into being in the various parts of the Commonwealth will, I am sure, long remain as monuments to an extremely creative and inspiring life. 